\title{
Adjustable mini-sling compared with conventional mid-urethral slings in women with urinary incontinence: a 3-year follow-up of a randomized controlled trial
}

\author{
Vasileios Alexandridis $^{1,2,3}$ - Martin Rudnicki ${ }^{4,5} \cdot$ Ulf Jakobsson $^{2,6} \cdot$ Pia Teleman ${ }^{1,2}$ \\ Received: 1 March 2019 / Accepted: 28 May 2019 / Published online: 20 June 2019 \\ (C) The Author(s) 2019
}

\begin{abstract}
Introduction and hypothesis The aim of this study was to compare the long-term subjective outcomes of an adjustable singleincision sling (Ajust $\AA^{\text {) }}$ vs standard mid-urethral slings (SMUS) for the treatment of women with stress urinary incontinence.

Methods This study was designed as a multicenter prospective randomized trial. Women under 60 years old with objectively verified stress urinary incontinence were included from seven centers in three countries. Women with mixed urinary incontinence were also included. Randomization was held in blocks for operation with either Ajust ${ }^{\circledR}$ or SMUS. Women analyzed at 1-year follow-up received the International Consultation on Incontinence Questionnaire Urinary Incontinence Short Form (ICIQ-UI$\mathrm{SF}$ ), International Consultation on Incontinence Questionnaire Overactive Bladder, Pelvic Organ Prolapse/Urinary Incontinence/ Sexual Function Questionnaire-12, Patient Global Impression of Severity, and Patient Global Impression of Improvement questionnaires, together with a bladder diary to fill out at least 3 years after the procedure. The main outcome evaluated was the subjective cure rate as reported through the ICIQ-UI-SF questionnaire at 3 years.

Results In total, 205 women participated in the 3-year follow-up: 107 in the Ajust ${ }^{\circ}$ and 98 in the SMUS group. No significant difference was observed between the groups regarding subjective cure rate $(50.9 \%$ vs $51.5 \%, p=0.909)$ or dyspareunia. Both groups demonstrated similar postoperative perception of improvement in addition to reduced urgency and urge urinary incontinence. The postoperative improvement remained at the same level after 3 years as it was at 1-year follow-up for both Ajust@ and SMUS.

Conclusions Ajust ${ }^{\circledR}$ appears to be equally effective and safe as SMUS with regard to long-term follow-up of patientreported outcomes.
\end{abstract}

Keywords Mid-urethral sling $\cdot$ Mini-sling $\cdot$ Single-incision sling $\cdot$ Stress urinary incontinence

International Continence Society 48th Annual Meeting, Philadelphia, 2831 August 2018 and 31st Bi-Annual Meeting of the Nordic Urogynecological Association, Copenhagen, 25-26 January 2019

Vasileios Alexandridis

alexandridisv@gmail.com

1 Department of Obstetrics and Gynecology, Skane University Hospital, Lund, Sweden

2 Faculty of Medicine, Lund University, Lund, Sweden

3 Department of Obstetrics and Gynecology, Skane University Hospital, Jan Waldenströms gata 47, 21466 Malmö, Sweden

4 Department of Obstetrics and Gynecology, Odense University Hospital, Odense, Denmark

5 Department of Clinical Research, University of Southern Denmark, Odense, Denmark

6 Center for Primary Healthcare Research, Clinical Research Center, Malmö, Sweden

$\begin{array}{ll}\text { Abbreviations } & \\ \text { ICIQ } & \begin{array}{l}\text { International Consultation on Incontinence } \\ \text { Questionnaire } \\ \text { International Consultation on Incontinence } \\ \text { Questionnaire Overactive Bladder } \\ \text { International Consultation on Incontinence } \\ \text { Questionnaire Urinary Incontinence } \\ \text { Short Form }\end{array} \\ \text { MUI } & \begin{array}{l}\text { Mixed urinary incontinence } \\ \text { Nordic Federation of Obstetrics } \\ \text { and Gynecology }\end{array} \\ \text { NFOG } & \begin{array}{l}\text { Overactive bladder } \\ \text { Patient Global Impression of Improvement }\end{array} \\ \text { PGI-I } & \begin{array}{l}\text { Patient Global Impression of Severity } \\ \text { PGI-S }\end{array} \\ \text { PISQ-12 } & \begin{array}{l}\text { Pelvic Organ Prolapse/Urinary } \\ \text { Incontinence/Sexual Function } \\ \text { Questionnaire }\end{array}\end{array}$




$\begin{array}{ll}\text { SIMS } & \text { Single-incision mid-urethral slings } \\ \text { SMUS } & \text { Standard mid-urethral slings } \\ \text { SUI } & \text { Stress urinary incontinence } \\ \text { TOT } & \text { Trans-obturator tape } \\ \text { TVT } & \text { Tension-free vaginal tape } \\ \text { TVT-O } & \text { Trans-obturator vaginal tape } \\ \text { UUI } & \text { Urge urinary incontinence }\end{array}$

\section{Introduction}

Single-incision mid-urethral slings (SIMS), or mini-slings, have been introduced over the past few years to minimize the surgical procedure and operation time and decrease the number of complications associated with surgery for the treatment of stress urinary incontinence (SUI). A recent metaanalysis reported insufficient results for the extraction of safe conclusions, but there is some evidence indicating better performance of the SIMS in terms of post-operative pain and duration of the operation [1]. On the other hand, the TVTSecur has consistently demonstrated inferior results compared with standard mid-urethral slings (SMUS) and has been withdrawn from the market $[2,3]$. These findings indicate the importance of the fixation system associated with each sling, as this aspect is suggested to be the main reason for the failure of the TVT-Secur [1]. Furthermore, long-term follow-up research is needed before introducing a new device into clinical practice. Such data concerning the long-term efficacy and safety of SIMS has, to our knowledge, not yet been published.

The lack of data is also apparent concerning the new device Ajust ${ }^{\circledR}$, which is an adjustable mini-sling that works in a similar manner to SMUS, as the tension of the sling can be modified during the procedure. Several studies have evaluated the short- to midterm efficacy of Ajust ${ }^{\circledR}$, demonstrating a subjective cure rate of $77-94 \%$ and a complications profile similar to that of trans-obturator vaginal tape (TVT-O) [4-17]. There is some evidence indicating greater costeffectiveness compared with TVT-O [18] and Ajust ${ }^{\circledR}$ has been shown to be easier to attach to the obturator complex than other mini-slings [19]. However, most of the studies concerning Ajust ${ }^{\circledR}$ demonstrate a follow-up period of around 1-2 years, with the exception of one study analyzing 3-year results [20]. Considering the initial promising results of the Ajust ${ }^{\circledR}$ sling, Rudnicki et al. published a randomized controlled trial in 2017, which was the first to compare Ajust ${ }^{\circledR}$ with SMUS other than TVT-O [21]. This study showed no significant difference in objective or subjective cure rates after 1 year and there was no difference observed in postoperative improvement or complication rates either. As early as during the design of this study, a 3-year follow-up was planned.

The primary aim of the present study was to compare the long-term subjective cure rate of Ajust ${ }^{\circledR}$ versus SMUS. The secondary aim was to compare the patient-reported improvement, complications, and symptoms regarding urinary incontinence and pelvic floor function 3 years after undergoing surgery with Ajust $\circledR^{\circ}$ versus SMUS.

\section{Materials and methods}

This study was designed as a prospective multicenter randomized clinical trial. It was funded by the Nordic Federation of Obstetrics and Gynecology (NFOG) Research Fund after an external evaluation by the NFOG Scientific Committee and approval by the NFOG Board. The funder was not involved in conducting this study in any way. Ajust ${ }^{\circledR}$ (Bard, Murray Hill, NJ, USA) was compared with the conventional mid-urethral slings tension-free vaginal tape (TVT) (Ethicon, Somerville, NJ, USA), TVT-O inside-out (Ethicon), and trans-obturator tape (TOT; Monarc; AMS, Minneapolis, MN, USA), depending on the type of the sling that each of the eight centers in Sweden, Denmark, and Norway preferred to use.

Randomization was carried out through a computergenerated list in blocks of 25 corresponding to each center in a ratio of $1: 1$ to either Ajust $₫$ or SMUS. A random allocation sequence was generated by an independent statistician and sealed, non-transparent envelopes were used during randomization. Data were recorded following inclusion. The followup conducted from inclusion up to 1 year is described in the study by Rudnicki et al. [21].

All women received oral and written information about the study protocol in advance and gave their consent to participation. Women participating had a medical history of either SUI, defined as the complaint of involuntary leakage of urine due to physical exertion, or mixed urinary incontinence (MUI), corresponding to women exhibiting SUI along with leakage associated with urgency. SUI had to be the dominating symptom and it was confirmed in all women included in the study by a positive standardized cough test with $300 \mathrm{~cm}^{3}$ water in the bladder. Medical history and physical examination were part of the pre-operative assessment and pelvic floor muscle training had failed or women had declined it.

Women were excluded if they were aged $>60$ years, had predominantly urge urinary incontinence (UUI), pelvic organ prolapse (Pelvic Organ Prolapse Quantification stage $\geq 2$ ), previous incontinence or pelvic organ prolapse surgery, planned or present pregnancy, residual urine volume $>100 \mathrm{ml}$, previous pelvic irradiation, repeated urinary tract infections (four or more during the previous year), neurological conditions such as multiple sclerosis, current treatment with corticoids, inability to understand the protocol, and a history of genital or abdominal cancer or a pelvic mass.

All centers except for one participated in the 3-year followup, i.e., seven centers. One center did not participate because of local logistics issues. All women who participated in the 1year follow-up received questionnaires at least 3 years after 
the Ajust ${ }^{\circledR}$ or SMUS procedure, which they were asked to fill out and submit. Along with the questionnaires, they received a bladder diary for 2 consecutive days. Women who did not respond were contacted with letters before exclusion.

All surgeons were specialized gynecologists and all had performed more than 100 SMUS procedures and at least two operations with Ajust ${ }^{\circledR}$ under an instructor's supervision before entering the study. The women received local, spinal or general anesthesia, depending on local regimens, and cystoscopy was performed perioperatively in all cases. The clinical part of the study, including selection of women and interventions, was carried out between May 2012 and April 2014.

No core outcome set regarding female pelvic floor disorders was available during the design phase of this study, but the development of one is currently ongoing. The outcomes chosen were in agreement with the International Consultation on Incontinence and the International Urogynecological Association recommendations for the evaluation of urinary incontinence and pelvic floor function in women $[22,23]$. The International Consultation on Incontinence Questionnaires (ICIQ), Urinary IncontinenceShort Form (ICIQ-UI-SF) and Overactive Bladder (ICIQ$\mathrm{OAB})$, the Patient Global Impression of Improvement (PGI-I) and the Patient Global Impression of Severity (PGI-S) questionnaires and, if sexually active, the Pelvic Organ Prolapse/Urinary Incontinence/Sexual Function
Questionnaire (PISQ-12) were used together with a 2-day bladder diary for the evaluation of the effect of the procedures on the women's pelvic tract and bladder symptoms in addition to quality of life parameters.

\section{Statistical analysis}

The study was designed as a randomized trial and one-sided power analysis that was conducted before randomization showed that the inclusion of 131 women was required in each arm anticipating a cure rate of not less than $9 \%$ for Ajust ${ }^{\circledR}$ compared with SMUS $(\alpha=0.05, \beta=0.2)$ [21]. Data were analyzed using descriptive and analytical statistics. When analyzing descriptive data, mean, standard deviation, and range were used for continuous data, whereas median, interquartile range, and frequencies ( $n$ and percentage) were used for ordinal and nominal data. Student's $t$ test was used for normally distributed data and, for ordinal and non-normally distributed data, the Mann-Whitney $U$ test or the Friedman test was used for comparison between groups. Post-hoc analysis of the Friedman test results was conducted using the Wilcoxon signed-rank test with a correction applied using the Bonferroni method $(\alpha=0.017)$. The Chi-squared test and Fisher's exact test were used for nominal data. All analyses were performed using IBM SPSS statistics (version 24) and the statistical significance was set at $<0.05$ (except for the post-hoc tests).
Fig. 1 Flow diagram of the study population. SMUS standard mid-urethral sling, TVT tension-free vaginal tape, TVT-O trans-obturator vaginal tape, TOT trans-obturator tape

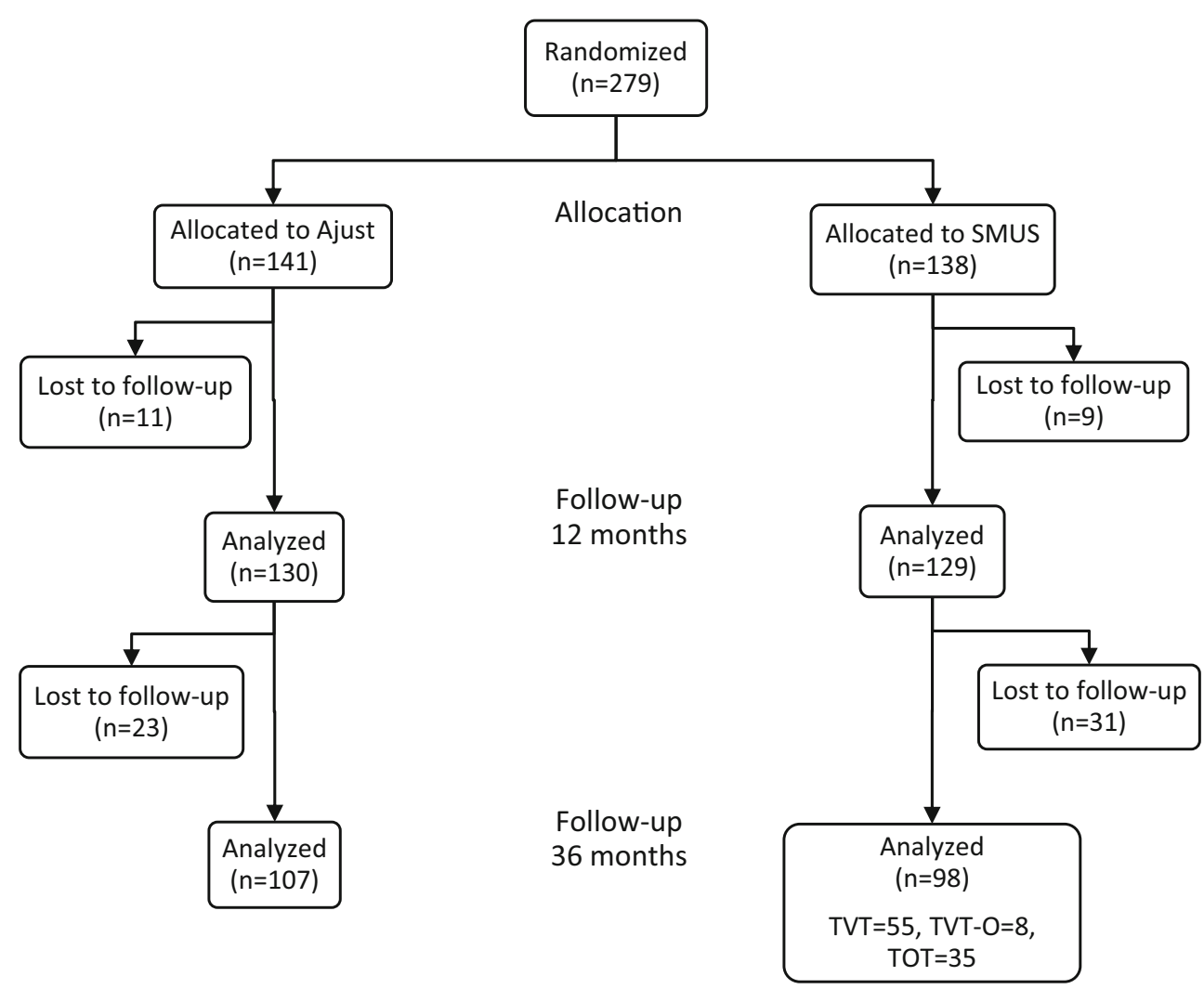




\section{Ethics approval}

Ethics approval of the study was obtained from the local ethics committee in each country; Denmark ref. no. SJ252 (approved by the local ethics committee of Region Zealand, Denmark), Sweden ref. no. 2011/529, 2012/42 (approved by the regional ethics committee in Lund, Sweden), Norway ref. no. 2011/ 2005A (Ethics committee of Norway, REK).

The trial was registered at ClinicalTrials.gov: NCT01754558.

Table 1 Descriptive characteristics at baseline of the 279 participants

\begin{tabular}{|c|c|c|c|}
\hline & Ajust $(n=141)$ & SMUS $(n=138)$ & $p$ value \\
\hline Age (years), mean $\pm \mathrm{SD}$ (range) & $44.9 \pm 6.8(27-59)$ & $45.9 \pm 7.3(27-60)$ & $0.228 *$ \\
\hline BMI $\left(\mathrm{kg} / \mathrm{m}^{2}\right)$, mean $\pm \mathrm{SD}$ (range) & $26.2 \pm 4.8(19-49)$ & $26.6 \pm 4.6(16-42)$ & $0.550^{*}$ \\
\hline Parity, median (IQR) & $2.0(1.0)$ & $2.0(1.0)$ & $0.697 * *$ \\
\hline Postmenopausal, $n(\%)$ & $28(20.3)$ & $32(24.4)$ & $0.415^{* *}$ \\
\hline On HRT, $n(\%)$ & $15(10.6)$ & $18(13.1)$ & $0.519 * *$ \\
\hline - Systemic HRT, $n(\%)$ & $6(17.6)$ & $5(14.7)$ & $0.745^{* *}$ \\
\hline - Vaginal HRT, $n(\%)$ & $10(30.3)$ & $13(37.1)$ & $0.551 * *$ \\
\hline Smokers, $n(\%)$ & $25(18.0)$ & $21(15.4)$ & $0.572 * *$ \\
\hline Diabetes, $n(\%)$ & $0(0.0)$ & $4(2.9)$ & $0.060 * * *$ \\
\hline Chronic obstructive lung disease, $n(\%)$ & $3(2.2)$ & $2(1.5)$ & $0.503 * * *$ \\
\hline Previous hysterectomy, $n(\%)$ & $15(10.7)$ & $15(10.9)$ & $0.967 * *$ \\
\hline Previous prolapse surgery, $n(\%)$ & $3(2.1)$ & $2(1.4)$ & $0.507 * * *$ \\
\hline - Anterior & $2(66.9)$ & $2(100)$ & \\
\hline - Anterior and posterior & $1(33.3)$ & $0(0.0)$ & \\
\hline \multicolumn{4}{|l|}{ Medication, $n(\%)$} \\
\hline - Diuretics & $3(2.1)$ & $4(2.9)$ & $0.722 * * *$ \\
\hline - Antidepressants & $8(5.8)$ & $6(4.4)$ & $0.603 * *$ \\
\hline Stress urinary incontinence, $n(\%)$ & $104(74.8)$ & $108(80.6)$ & $0.252 * *$ \\
\hline Mixed urinary incontinence, $n(\%)$ & $36(26.1)$ & $29(21.2)$ & $0.337 * *$ \\
\hline Number of micturitions per day, mean \pm SD (range) $^{\mathrm{a}}$ & $7.2 \pm 2.1(3-15)$ & $7.0 \pm 1.7(3-13)$ & $0.259 *$ \\
\hline Incontinence episodes per day, mean $\pm \mathrm{SD}$ (range) ${ }^{\mathrm{a}}$ & $3.2 \pm 3.4(0-24)$ & $3.3 \pm 4.0(0-26)$ & $0.721 *$ \\
\hline ICIQ score, median (IQR) & $15.0(5.0)$ & $15.0(4.0)$ & $0.106 * * * *$ \\
\hline Residual volume, median (IQR) & $5.0(30.0)$ & $2.5(19.3)$ & $0.037 * * * *$ \\
\hline Flow max rate $(\mathrm{ml} / \mathrm{s})$, mean $\pm \mathrm{SD}$ & $27.9 \pm 8.5$ & $27.6 \pm 12.5$ & $0.897 *$ \\
\hline Dyspareunia, PISQ-12 (\%) & & & $0.505 * * * *$ \\
\hline - Always & 1.6 & 0.9 & \\
\hline - Usually & 2.5 & 2.6 & \\
\hline - Sometimes & 21.3 & 23.1 & \\
\hline - Seldom & 30.3 & 35.0 & \\
\hline - Never & 44.3 & 38.5 & \\
\hline
\end{tabular}

Text in bold indicates statistical significance

SMUS standard mid-urethral sling, $B M I$ body mass index, $I Q R$ interquartile range, $H R T$ hormone replacement therapy, ICIQ International Consultation on Incontinence Questionnaire, PISQ-12 Pelvic Organ Prolapse/Urinary Incontinence/Sexual Function Questionnaire

*Student's $t$ test

**Chi-squared test

***Fisher's exact test

*****Mann-Whitney $U$ test

${ }^{\text {a }}$ Calculated from the bladder diary
URL: clinicaltrials.gov/ct2/show/NCT01754558?term= NCT01754558\&rank=1

\section{Results}

In total, 279 women from the seven centers in Sweden, Denmark, and Norway that participated in the 3-year followup were initially randomized between Ajust $\AA$ and SMUS. Of those women, 259 were enlisted for 1-year follow-up. The 
results of 205 women were further analyzed 3 years after the Ajust ${ }^{\circledR}$ or SMUS operation, corresponding to $73 \%$ of the women analyzed in the 1-year follow-up study [21]. The Ajust ${ }^{\circledR}$ group consisted of 107 women and the SMUS group of 98 , which was equivalent to $76 \%$ and $71 \%$ respectively of those initially included. Detailed information, in addition to the distribution among the various SMUS, is shown in Fig. 1. The women in both groups had the same characteristics at baseline and similar bladder function (Table 1).

The 3-year follow-up showed no difference in the subjective cure rate, which was defined as the proportion of women reporting no leakage at all in the ICIQ-UI-SF. The percentage of women who stated having no urinary incontinence whatsoever 3 years after the procedure was $50.9 \%$ vs $51.5 \%$ for the Ajust ${ }^{\circledR}$ vs the SMUS group respectively $(p=0.909)$. The corresponding cure rates based on the 2-day bladder diary were $71.1 \%$ for the Ajust ${ }^{\circledR}$ versus $82.9 \%$ for the SMUS group with no significant difference either $(p=0.481)$. However, women in the Ajust@ group demonstrated a significantly lower number of micturitions per day (6.1 vs 6.7; $p=0.040$; Table 2).
The ICIQ-UI-SF score sum was equally reduced in both groups at 3-year follow-up ( $p=0.660$; Table 2 ) and equal over-the-time improvement was also observed regarding urgency and UUI based on the ICIQ-OAB questions 5a and $6 a$ (Table 3). Both groups demonstrated the same degree of improvement as stated in the PGI-I questionnaire, with the percentage of women reporting significantly or much improved 3 years after the operation with Ajust ${ }^{\circledR}$ being $95.1 \%$ versus $89.7 \%$ for the women who received an SMUS. For both groups the improvement increased through the first post-operative year, remaining stable at the same level during the 3-year follow-up. The same pattern was observed using the PGI-S questionnaire with equal degrees of improvement of the severity status after 3 years between the groups, which was stable compared with the 1-year results (Table 4). Similarly, there was no difference observed in the percentage of women reporting dyspareunia after the operation or in the PISQ-12 score sum (Table 2). No major adverse events other than those reported at the 1-year follow-up were later recorded.
Table 2 Results at 36-months follow-up

\begin{tabular}{|c|c|c|c|}
\hline & Ajust $(n=107)$ & SMUS $(n=98)$ & $p$ value \\
\hline \multicolumn{4}{|l|}{ Subjective cure rate, ICIQ-UI-SF (\%) } \\
\hline Question 3: "How often do you leak urine?" & & & $0.909^{*}$ \\
\hline - Never & 50.9 & 51.5 & \\
\hline - About once a week or less often & 31.1 & 32.0 & \\
\hline - Two or three times a week & 12.3 & 10.3 & \\
\hline - Once daily & 3.8 & 1.0 & \\
\hline - Several times a day & 1.9 & 5.2 & \\
\hline - All the time & - & - & \\
\hline ICIQ score sum, questions 3-5 (mean $\pm \mathrm{SD})$ & $2.8 \pm 3.6$ & $3.0 \pm 3.9$ & $0.660 * *$ \\
\hline Number of micturitions per day (mean \pm SD) & $6.1 \pm 1.4$ & $6.7 \pm 1.8$ & $0.040 * *$ \\
\hline Incontinence episodes, bladder diary, $n(\%)$ & & & $0.481 *$ \\
\hline - Zero episodes & $27(71.1)$ & $29(82.9)$ & \\
\hline - One episode & $5(13.2)$ & $3(8.6)$ & \\
\hline - Two episodes & $4(10.5)$ & $1(2.9)$ & \\
\hline - Three episodes & $1(2.6)$ & - & \\
\hline - Four episodes & - & $2(5.8)$ & \\
\hline$->$ Four episodes & $1(2.6)$ & - & \\
\hline Dyspareunia, PISQ-12 (\%) & & & $0.496^{*}$ \\
\hline - Always & 0.0 & 1.3 & \\
\hline - Usually & 4.5 & 1.3 & \\
\hline - Sometimes & 15.7 & 10.0 & \\
\hline - Seldom & 22.5 & 41.3 & \\
\hline - Never & 57.3 & 46.3 & \\
\hline PISQ-12 score sum $($ mean \pm SD) & $36.1 \pm 3.7$ & $35.1 \pm 3.7$ & $0.086^{*}$ \\
\hline
\end{tabular}

Text in bold indicates statistical significance

*Mann-Whitney $U$ test

**Student's $t$ test 
Table 3 International Consultation on Incontinence Questionnaire Overactive Bladder (ICIQ-OAB) results of the 205 women analyzed after 36 months

\begin{tabular}{|c|c|c|c|c|}
\hline & Baseline & 12 months & 36 months & $p$ value (post-hoc) \\
\hline \multicolumn{4}{|c|}{ ICIQ-OAB, Question 5a (Ajust) \% } & $<0.001 *$ \\
\hline \multicolumn{4}{|c|}{ "Do you have to rush to the toilet to urinate?" } & $(\mathrm{A}, \mathrm{B})$ \\
\hline - Never & 15.8 & 31.1 & 28.3 & \\
\hline - Rarely & 33.7 & 43.7 & 48.1 & \\
\hline - Sometimes & 38.6 & 19.4 & 17.9 & \\
\hline - Often & 10.9 & 4.9 & 4.7 & \\
\hline - Always & 1.0 & 1.0 & 0.9 & \\
\hline \multicolumn{4}{|c|}{ ICIQ-OAB, Question 5a (SMUS) \% } & $<0.001 *$ \\
\hline \multicolumn{4}{|c|}{ "Do you have to rush to the toilet to urinate?" } & $(A, B)$ \\
\hline - Never & 14.0 & 29.9 & 28.6 & \\
\hline - Rarely & 36.6 & 46.0 & 37.8 & \\
\hline - Sometimes & 44.1 & 24.1 & 28.6 & \\
\hline - Often & 5.4 & - & 5.1 & \\
\hline - Always & - & - & - & \\
\hline \multicolumn{4}{|c|}{ ICIQ-OAB, Question 6a (Ajust) \% } & $<0.001 *$ \\
\hline \multicolumn{4}{|c|}{ "Does urine leak before you can get to the toilet?" } & $(A, B)$ \\
\hline - Never & 21.6 & 50.4 & 48.1 & \\
\hline - Rarely & 27.0 & 35.0 & 31.1 & \\
\hline - Sometimes & 36.0 & 12.2 & 18.9 & \\
\hline - Often & 12.6 & 2.4 & 1.9 & \\
\hline - Always & 2.7 & - & - & \\
\hline \multicolumn{4}{|c|}{ ICIQ-OAB, Question 6a (SMUS) \% } & $<0.001 *$ \\
\hline \multicolumn{4}{|c|}{ "Does urine leak before you can get to the toilet?" } & $(A, B)$ \\
\hline - Never & 22.4 & 56.5 & 50.0 & \\
\hline - Rarely & 36.4 & 33.0 & 30.2 & \\
\hline - Sometimes & 33.6 & 7.8 & 15.6 & \\
\hline - Often & 5.6 & 1.7 & 3.1 & \\
\hline - Always & 1.9 & 0.9 & 1.0 & \\
\hline
\end{tabular}

Post-hoc test: significant difference between $\mathrm{A}=$ baseline and 12 months, $\mathrm{B}=$ baseline and 36 months, $\mathrm{C}=12$ and 36 months. Text in bold indicates statistical significance

*Friedman test with Wilcoxon signed-rank test as post-hoc, Bonferroni method $\rightarrow \alpha=0.017$

\section{Discussion}

\section{Main findings}

Based on the results of this study, Ajust ${ }^{\circledR}$ demonstrates equal efficacy and safety to the widely used mid-urethral slings, whose characteristics have been confirmed by years of clinical experience and long-term follow-up trials. Furthermore, both methods seem to have a positive effect on overactive bladder (OAB) symptoms. This has been shown in other studies evaluating the effect of surgical treatment for MUI and it has been used as an argument by those supporting a common urethrogenic mechanism as the cause of both SUI and UUI
[24]. Compared with the 1-year results from the study of Rudnicki et al. [21], the 3-year outcomes do not differ substantially regarding the cure rates, the OAB symptoms, the perception of improvement or the dyspareunia for either Ajust ${ }^{\circledR}$ or SMUS. This is confirmed by the analysis of the outcomes in our group of women over time, suggesting an invariable efficacy and safety of Ajust $₫$ after the first year and up to 3 years. The same was observed through long-term follow-up studies of conventional TVT slings that demonstrated only a small decrease in their effect over the years [25].

\section{Strengths and limitations}

There are some limitations regarding this study. Our results are patient-reported and they are limited to 3 years after the operation. Objective data could not be obtained owing to a lack of alignment among the centers participating in the study. Sensitivity analysis was not done as we did not observe any tendency for any of the groups to consistently overcome the others and there were no signs of non-significant $p$ values due to the sample size. Selection bias may occur, but the number of women missing at the 3-year follow-up is balanced between the two groups. In fact, the women who did not respond to our invitations were of lower age in both groups. One explanation may be that a large number of those women did not respond because they were satisfied with the operation and in that way we may have underestimated to some extent the cure rates in both groups. We have no reason to believe that the one missing center in particular would affect the outcomes of the study, based on the 1-year results. The women included in this study were under 60 years of age and the conclusions do not apply beyond this age group.

The strength of our study lies in the large number of women recruited, in addition to the multicenter, randomized design, which allows the comparison of Ajust ${ }^{\circledR}$ with other established mid-urethral slings. Additionally, in our study not just one sling was used in the control group, but each center used the type of sling they preferred, making it easier to generalize the conclusions. A recent meta-analysis has in fact demonstrated that all three SMUS used in our study are equally effective [26]. Moreover, Ajust ${ }^{\circledR}$ was not proven to be inferior to SMUS, despite the fact that surgeons were not equally familiar with the Ajust ${ }^{\circledR}$ procedure.

\section{Interpretation}

This study is one of only two evaluating the performance of Ajust ${ }^{\circledR}$ separately and one of few evaluating the performance of adjustable mini-slings as a group for periods longer than 2 years [20, 25-27]. Therefore, the comparison of our results with those of other studies presents significant difficulties. Kluz et al. [20] reported recently in a retrospective design on the outcomes of Ajust ${ }^{\circledR} 36-$ 
Table 4 Patient Global Impression of Severity (PGI-S) and Patient Global Impression of Improvement (PGI-I) results of the 205 women analyzed after 36 months

\begin{tabular}{lllllll}
\hline & $\begin{array}{l}\text { Ajust } \\
\text { baseline }\end{array}$ & $\begin{array}{l}\text { Ajust } \\
12 \text { months }\end{array}$ & $\begin{array}{l}\text { Ajust } \\
36 \text { months }\end{array}$ & $\begin{array}{l}\text { SMUS } \\
\text { baseline }\end{array}$ & $\begin{array}{l}\text { SMUS } \\
12 \text { months }\end{array}$ & $\begin{array}{l}\text { SMUS } \\
36 \text { months }\end{array}$ \\
\hline $\begin{array}{lllll}\text { PGI-S, \%* } \\
- \text { Normal }\end{array}$ & 28 & 72.3 & & & & \\
- Minor & 5.0 & 25.7 & 27.9 & 12.1 & 13.6 & 22.7 \\
- Moderate & 40.0 & 2.0 & 2.9 & 38.5 & - & 6.2 \\
- Severe & 27.0 & - & 1.0 & 17.6 & - & 1.0 \\
PGI-I, \%** & & & & & & \\
- Very much improved & - & 75.0 & 71.6 & - & 89.5 & 75.3 \\
- Much improved & - & 19.0 & 23.5 & - & 4.7 & 14.4 \\
- Minimally improved & - & 4.0 & 3.9 & - & 3.5 & 7.2 \\
- - Unchanged & - & 2.0 & - & - & 1.2 & 2.1 \\
- Minimally worse & - & - & - & - & - & - \\
- Much worse & - & - & - & - & - & 1.0 \\
- Very much worse & - & - & 1.0 & - & 1.2 & - \\
\hline
\end{tabular}

Ajust: $n=107$, SMUS: $n=98$

*Comparison of PGI-S between Ajust and SMUS at baseline; $\boldsymbol{p}=\mathbf{0 . 0 3 3}, 12$ months; $p=0.115$ and 36 months; $p=0.913$ (Mann-Whitney $U$ test)

**Comparison of PGI-I between Ajust and SMUS at 12 months; $\boldsymbol{p}=\mathbf{0 . 0 2 8}$ and 36 months; $p=0.759$ (MannWhitney $U$ test)
50 months after the operation. The post-operative evaluation was carried out through a combination of interview and examination and the observed cure rate of $51.6 \%$ is in agreement with our results based on the ICIQ-UI-SF. However, the cure rates reported by the remaining studies evaluating the efficacy of Ajust ${ }^{\circledR}$ up to 2 years are significantly higher at around $85 \%$ [4-17]. On the other hand, the cure rate we observed of $71.1-82.9 \%$ based on the bladder diary was comparable with these studies and the same was observed for the percentage of women who reported being significantly/much better after both procedures, which was up to $95.1 \%$. This discrepancy can be justified by the more objective character of the bladder diary in addition to its shorter period of registration, probably resulting in higher specificity, whereas the ICIQ provides a more comprehensive impression of the women's symptoms, which in turn may generate greater sensitivity for detecting incontinence and, therefore, lower cure rates. After all, the correlation between data derived from bladder diaries and questionnaires regarding urinary incontinence is generally known to be weak [28]. However, it is to be noted that the bladder diary was submitted by significantly fewer women than those who answered the questionnaires.

In addition to the different ways in which cure is defined by each study group, variation in follow-up periods and study populations possibly also contributes to the different outcomes. The inclusion of women with MUI in our study certainly lowers the percentage of those reporting no leakage at all after the procedure, which was our primary outcome. In any case, the randomized design allows us to compare Ajust ${ }^{\circledR}$ with other slings with an established effect on incontinence, showing no significant difference, which is in agreement with the results of the other studies comparing Ajust ${ }^{\circledR}$ with TVT-O [7, 9-11, 13, 15-17]. Our findings are also in accordance with the results of meta-analyses regarding patient-reported cure rates for both short- and long-term follow-up periods, when comparing conventional mid-urethral slings with SIMS all together and with Ajust separately [29], likewise when comparing SMUS with the group of adjustable SIMS [30].

Ajust ${ }^{\circledR}$, along with other mesh devices, has recently been withdrawn from the market. The manufacturing company declares only business reasons for this removal and no safety concerns whatsoever, asking at the same time for the immediate removal even of the unused devices. It remains to be seen if the results of long-term follow-up trials could have an impact on this decision. It is worth mentioning that this study was not funded in any way by the industry. We believe that such data should actually be provided by the company introducing a device and not by a study group interested in the security and efficacy of a new treatment available commercially. However, studies like this are important to minimize the risk of widely using a device without knowledge of potential adverse effects, in addition to acting as a springboard for future development.

\section{Conclusion}

Our study shows that Ajust ${ }^{\circledR}$ is not inferior to the conventional mid-urethral slings regarding long-term follow-up periods. 
Our results, combined with the association of the failure of other mini-slings mainly with their inadequate fixation system, indicate that the presence of an efficient fixation in the obturator complex makes the potentially harmful penetration into deeper layers unnecessary. Further research is needed with longer follow-up periods and objective data to examine the possible benefits of mini-slings and gradually even the development of better devices.

Acknowledgements We thank Katarina von Bothmer Östling from Halmstad Hospital in Sweden, Anja Holstad from Gjøvik Hospital in Norway, Claes Magnusson from Sahlgrenska University Hospital in Sweden, Memona Majida from Ahus University Hospital in Norway, and Constanze Merkel from Regional Hospital of Northern Jutland in Denmark for their vital contribution to the development of this project. We also thank all the women who participated in this study and shared their experiences.

Funding This study was funded by the Nordic Federation of Obstetrics and Gynecology Research Fund. Grant No. NF12013.

\section{Compliance with ethical standards}

\section{Conflicts of interest None.}

Open Access This article is distributed under the terms of the Creative Commons Attribution 4.0 International License (http:// creativecommons.org/licenses/by/4.0/), which permits unrestricted use, distribution, and reproduction in any medium, provided you give appropriate credit to the original author(s) and the source, provide a link to the Creative Commons license, and indicate if changes were made.

\section{References}

1. Nambiar A, Cody JD, Jeffery ST, Aluko P. Single-incision sling operations for urinary incontinence in women. Cochrane Database Syst Rev. 2017;7:CD008709.

2. Andrada Hamer M, Larsson P-G, Teleman P, Bergqvist CE, Persson J. One-year results of a prospective randomized, evaluator-blinded, multicenter study comparing TVT and TVT Secur. Int Urogynecol J. 2013;24(2):223-9.

3. Huang W, Wang T, Zong H, Zhang Y. Efficacy and safety of tension-free vaginal tape-secur mini-sling versus standard midurethral slings for female stress urinary incontinence: a systematic review and meta-analysis. Int Neurourol J. 2015;19(4):246-58.

4. Meschia M, Barbacini P, Baccichet R, Buonaguidi A, Maffiolini M, Ricci L, et al. Short-term outcomes with the Ajust ${ }^{\mathrm{TM}}$ system: a new single incision sling for the treatment of stress urinary incontinence. Int Urogynecol J. 2011;22(2):177-82.

5. Abdel-Fattah M, Agur W, Abdel-All M, Guerrero K, Allam M, Mackintosh A, et al. Prospective multi-centre study of adjustable single-incision mini-sling (Ajust(®)) in the management of stress urinary incontinence in women: 1-year follow-up study. BJU Int. 2012;109(6):880-6.

6. Cornu J-N, Peyrat L, Skurnik A, Ciofu C, Lucente VR, Haab F. Ajust single incision transobturator sling procedure for stress urinary incontinence: results after 1-year follow-up. Int Urogynecol J. 2012;23(9):1265-70.
7. Mostafa A, Agur W, Abdel-All M, Guerrero K, Lim C, Allam M, et al. A multicentre prospective randomised study of single-incision mini-sling (Ajust ${ }^{\circledR}$ ) versus tension-free vaginal tape-obturator (TVT-O ${ }^{\mathrm{TM}}$ ) in the management of female stress urinary incontinence: pain profile and short-term outcomes. Eur J Obstet Gynecol Reprod Biol. 2012;165(1):115-21.

8. Naumann G, Hagemeier T, Zachmann S, Al-Ani A, Albrich S, Skala C, et al. Long-term outcomes of the Ajust adjustable singleincision sling for the treatment of stress urinary incontinence. Int Urogynecol J. 2013;24(2):231-9.

9. Mostafa A, Agur W, Abdel-All M, Guerrero K, Lim C, Allam M, et al. Multicenter prospective randomized study of single-incision mini-sling vs tension-free vaginal tape-obturator in management of female stress urinary incontinence: a minimum of 1-year follow-up. Urology. 2013;82(3):552-9.

10. Grigoriadis C, Bakas P, Derpapas A, Creatsa M, Liapis A. Tensionfree vaginal tape obturator versus Ajust adjustable single incision sling procedure in women with urodynamic stress urinary incontinence. Eur J Obstet Gynecol Reprod Biol. 2013;170(2):563-6.

11. Martan A, Krhut J, Mašata J, Švabík K, Halaška M, Horčička L, et al. Prospective randomized study of MiniArc and Ajust single incision sling procedures. Low Urin Tract Symptoms. 2014;6(3):172-4.

12. Natale F, Dati S, La Penna C, Rombolà P, Cappello S, Piccione E. Single incision sling (Ajust ${ }^{\mathrm{TM}}$ ) for the treatment of female stress urinary incontinence: 2-year follow-up. Eur J Obstet Gynecol Reprod Biol. 2014;182:48-52.

13. Schweitzer KJ, Milani AL, van Eijndhoven HWF, Gietelink DA, Hallensleben E, Cromheecke G-J, et al. Postoperative pain after adjustable single-incision or transobturator sling for incontinence: a randomized controlled trial. Obstet Gynecol. 2015;125(1):27-34.

14. Jiang T, Xia Z, Cheng D, Song Y, Guo Z, Hu Q, et al. Short-term outcomes of adjustable single-incision sling (Ajust ${ }^{\mathrm{TM}}$ ) procedure for stress urinary incontinence: a prospective single-center study. Eur J Obstet Gynecol Reprod Biol. 2015;186:59-62.

15. Xin X, Song Y, Xia Z. A comparison between adjustable singleincision sling and tension-free vaginal tape-obturator in treating stress urinary incontinence. Arch Gynecol Obstet. 2016;293(2):457-63.

16. Masata J, Svabik K, Zvara K, Hubka P, Toman A, Martan A. Comparison of the efficacy of tension-free vaginal tape obturator (TVT-O) and single-incision tension-free vaginal tape (Ajust ${ }^{\mathrm{TM}}$ ) in the treatment of female stress urinary incontinence: a 1-year followup randomized trial. Int Urogynecol J. 2016;27(10):1497-505.

17. Sabadell J, Palau-Gené M, Huguet E, Montero-Armengol A, Salicrú S, Poza JL. Multicentre randomized trial of the Ajust ${ }^{\mathrm{TM}}$ single-incision sling compared to the align ${ }^{\mathrm{TM}}$ transobturator tape sling. Int Urogynecol J. 2017;28(7):1041-7.

18. Boyers D, Kilonzo M, Mostafa A, Abdel-Fattah M. Comparison of an adjustable anchored single-incision mini-sling, Ajust(®), with a standard mid-urethral sling, TVT-O(TM): a health economic evaluation. BJU Int. 2013;112(8):1169-77.

19. Lenz F, Doll S, Sohn C, Brocker KA. Single-incision mini-slings: obturator complex pull-out-force measurements. Gynecol Obstet Investig. 2017;82(4):376-81.

20. Kluz T, Wlaźlak E, Wróbel A, Wlaźlak W, Pazdrak M, Surkont G. Adjustable single incision sling Ajust - the effects of first operations controlled by pelvic floor sonography. Ginekol Pol. 2017;88(8):407-13.

21. Rudnicki M, von Bothmer-Ostling K, Holstad A, Magnusson C, Majida M, Merkel C, et al. Adjustable mini-sling compared with conventional mid-urethral slings in women with urinary incontinence. A randomized controlled trial. Acta Obstet Gynecol Scand. 2017;96(11):1347-56.

22. Staskin D, Kelleher C, Avery K, Bosch R, Cotterill N, Coyne K, et al. Initial assessment of urinary and faecal incontinence in adult male and female patients. Incontinence. 2009;4:331-412. 
23. Rogers RG, Coates KW, Kammerer-Doak D, Khalsa S, Qualls C. A short form of the pelvic organ prolapse/urinary incontinence sexual questionnaire (PISQ-12). Int Urogynecol J Pelvic Floor Dysfunct. 2003;14(3):164-8 discussion 168.

24. Anger JT, Rodríguez LV. Mixed incontinence: stressing about urge. Curr Urol Rep. 2004;5(6):427-31.

25. Nakamura R, Yao M, Maeda Y, Fujisaki A, Sekiguchi Y. Outpatient mid-urethral tissue fixation system sling for urodynamic stress urinary incontinence: 3 -year surgical and quality of life results. Int Urogynecol J. 2017;28(11):1733-8.

26. Petros PEP, Richardson PA. Midurethral tissue fixation system (TFS) sling for cure of stress incontinence-3 year results. Int Urogynecol J Pelvic Floor Dysfunct. 2008;19(6):869-71.

27. Sivaslioglu AA, Unlubilgin E, Aydogmus S, Keskin L, Dolen I. A prospective randomized controlled trial of the transobturator tape and tissue fixation mini-sling in patients with stress urinary incontinence: 5-year results. J Urol. 2012;188(1):194-9.
28. Donovan J, Bosch R, Gotoh M, Jackson S, Naughton M, Radley S, et al. Symptom and quality of life assessment. Incontinence. 2005;3:519-84.

29. Kim A, Kim MS, Park Y-J, Choi WS, Park HK, Paick SH, et al. Clinical outcome of single-incision slings, excluding TVT-Secur, vs standard slings in the surgical management of stress incontinence: an updated systematic review and meta-analysis. BJU Int. 2019;123(4):566-84.

30. Mostafa A, Lim CP, Hopper L, Madhuvrata P, Abdel-Fattah M. Single-incision mini-slings versus standard midurethral slings in surgical management of female stress urinary incontinence: an updated systematic review and meta-analysis of effectiveness and complications. Eur Urol. 2014;65(2):402-27.

Publisher's note Springer Nature remains neutral with regard to jurisdictional claims in published maps and institutional affiliations. 